\title{
Kreativitas Karyawan yang Kena PHK di Masa Pandemi Covid-19 dalam Menciptakan Lapangan Pekerjaan Baru
}

\section{Selviani Lobo Bala1*, Johnson Dongoran²}

1,2 Universitas Kristen Satya Wacana, Salatiga, Indonesia

\section{ART ICLE INF O}

\section{Article history:}

Received August 15, 2021

Revised August 19, 2021

Accepted October 03, 2021

Available online October 25, 2021

Kata Kunci:

Creating Jobs, Covid-19 Pandemic

Employee Creativity

Keywords:

PHK, Pandemi Covid-19, Kreativitas Karyawan

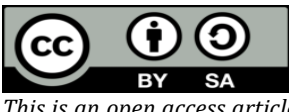

This is an open access article under the $\mathrm{CC}$ BY-SA license.

Copyright (C) 2021 by Author. Published by Universitas Pendidikan Ganesha.

\begin{abstract}
A B S T R A K
Salah satu dampak dari pandemi covid-19 adalah maraknya Pemutusan Hubungan Kerja (PHK). Tujuan penelitian ini adalah menganalisis kreativitas karyawan yang kena PHK di masa pandemi covid-19 dalam menciptakan lapangan pekerjaan baru. Penelitian ini merupakan penelitian kualitatif dengan teknik pengambilan sampel menggunakan metode purposive sampling yaitu responden yang benar-benar terkena PHK selama masa pandemi covid-19. Jumlah sampel yang digunakan yaitu 10 karyawan yang terkena PHK selama masa pandemi covid-19. Sumber data yang digunakan dalam penelitian ini adalah data primer yang diperoleh langsung dari responden melalui kuesioner. Kuesioner yang digunakan merupakan jenis kuesioner terbuka. Data dianalisis menggunakan teknik analisis deskriptif kualitatif. Hasil penelitian menunjukkan bahwa kreativitas karyawan dalam penciptaan lapangan kerja baru sama dengan teori mencakup 16 hal yaitu rasa ingin tahu yang besar, memiliki pendapat sendiri, memiliki gagasan pemecah masalah, dapat bekerja sendiri, senang mencoba hal-hal baru, memiliki kemampuan elaborasi, bersikap terbuka terhadap pengalaman baru, inovatif, keinginan untuk menemukan dan meneliti, kelancaran, fleksibel, bekerja keras, pantang menyerah, berkomunikasih dengan baik, suka berimajinasi dan dapat mencari solusi dari masalah.
\end{abstract}

\section{A B S T R A C T}

One of the impacts of the COVID-19 pandemic is the rise of layoffs. The purpose of this study was to analyze the creativity of employees who were laid off during the COVID-19 pandemic in creating new jobs. This research is a qualitative study with a sampling technique using the purposive sampling method, namely respondents who were actually laid off during the COVID-19 pandemic. The number of samples used were 10 employees who were laid off during the COVID-19 pandemic. Sources of data used in this study is primary data obtained directly from respondents through questionnaires. The questionnaire used is an open questionnaire. Data were analyzed using qualitative descriptive analysis techniques. The results showed that the creativity of employees in creating new jobs is the same as the theory which includes 16 things, namely great curiosity, having their own opinions, having problem solving ideas, being able to work alone, happy to try new things, having elaboration skills, being open. towards new experiences, innovative, desire to find and research, fluency, flexibility, hard work, never give up, communicate well, like to imagine and can find solutions to problems..

\section{PENDAHULUAN}

Di Indonesia, kebijakan yang dikeluarkan pemerintah untuk membatasi penyebaran Covid-19 harus terus dikaji dan dievaluasi secara serius, agar para pelaku UMKM tetap produktif dan dapat mendukung roda perekonomian nasional (Awali, 2020; Pakpahan, 2020). Pandemi Covid-19 membawa dampak signifikan bagi seluruh sisi kehidupan masyarakat, terlebih lagi bagi para pelaku usaha koperasi, usaha mikro, kecil, dan menengah yang perputaran ekonominya sangat bergantung pada rutinitas lalu lintas barang, jasa, dan manusia, yang saat ini sedang mengalami masa keterbatasan pergerakan atau PSBB (Djatmiko \& Pudyastiwi, 2020; Ningsih \& Mahfudz, 2020). Hal ini dapat mengakibatkan terjadinya penurunan produktivitas pada seluruh komponen dalam ekosistem UMKM dan juga turut berpengaruh pada keberlanjutan usaha dan kesejahteraan para pelaku UMKM, serta menurunnya daya beli masyarakat (Febriyanti, 2020; Nasution et al., 2020). Adanya wabah virus corona ini mempengaruhi banyak aspek kehidupan, salah satunya berpengaruh pada lapangan pekerjaan.

Salah satu dampak dari pandemi covid-19 adalah maraknya Pemutusan Hubungan Kerja (PHK). Data yang dipublikasikan dalam Tempo menunjukkan jumlah pekerja yang di PHK telah mencapai 3,05 juta (Putri \& Irwansyah, 2020). Sementara menurut survei Badan Pusat Statistik (BPS), penduduk berpendapatan rendah dan pekerja di sektor informal adalah kelompok yang paling terdampak dari Covid19. Kondisi agak berbeda di perkotaan yang terdampak adalah bisnis atau perdagangan. Gelombang PHK 
naik signifikan selama 9 bulan terakhir. Pada masa pandemi Covid-19 umumnya pemutusan hubungan kerja (PHK) karena alasan force majeure (keadaan memaksa) dan efisiensi (Muslim, 2020). Dampak pandemi Covid-19, selain pekerja di-PHK, Sebagian pekerja "dirumahkan", pemutusan kontrak kerja sebelum berakhir, pemotongan upah, hingga memberlakukan prinsip no work no pay (tidak bekerja, tidak dibayar) (Maringan, 2015; Wibowo \& Herawati, 2021). Akibat dari pandemi ini terjadi penurunan produksi karena berkurangnya permintaan dalam negeri dan pasar ekspor. Sehingga perusahaan tekstil terpaksa melakukan PHK kemudian mengalihkan produksinya ke (APD) Alat Pelindung Diri. Karyawan yang terkena PHK didukung untuk menciptakan kreativitas industri kecil menengah. Hal tersebut tentu sangat mempengaruhi pekerja dan karyawan perusahaan tersebut, di mana perusahaan tersebut tidak mampu membayar gaji para pekerjanya, sehingga menyebabkan banyak pekerja yang mengalami PHK (Arif, 2020).

Merambaknya virus corona membuat karyawan banyak menciptakan pekerjaan baru. Menciptakan pekerjaan bukan hanya merupakan solusi untuk memperoleh pekerjaan yang diinginkan, yang paling penting adalah kreativitas seorang dalam menciptakan pekerjaan sehingga membangun dan menumbuhkan ide kerja baru (Cheng et al., 2020; Maliwemu et al., 2021). Memasuki masa new normal pasca pandemi Covid-19, Organisasi Buruh Internasional (ILO) mengataka bahwa pentingnya penciptaan lapangan kerja untuk membantu mengurangi peningkatan jumlah pengangguran. Menciptakan merupakan gambaran ide baru yang pertumbuhan ekonominya dapat mengikuti penciptaan lapangan pekerjaan yang dikembangkan oleh(Adriani \& Wildayana, 2015). Pekerjaan baru tercipta pada saat peluang pekerja menggambarkan tersedianya lapangan pekerjaan yang di isi oleh para pencari kerja (Khusnani et al. 2019). Covid-19 akan menambah pengangguran di Indonesia yang bahkan sebelum pandemi angkanya mencapai 20,4 persen atau sudah cukup tinggi dibandingkan rata-rata global. Tantangan dalam penciptaan pekerjaan di masa new normal yaitu menyeimbangkan kebijakan di sektor kesehatan, ekonomi, dan sosial yang baru. Pandemi covid-19 telah memaksa restoran, toko, bioskop dan bisnis di seluruh dunia menanggung krisis, namun pada saat ini krisis kesehatan telah menciptakan beberapa pekerjaan baru (Annisa, 2020). Pekerjaan tidak selamanya disediakan oleh perusahaan besar dan pemerintah saja tetapi dapat diciptakan dengan mengandalkan keahlian yang dimiliki. Jika menciptakan lapangan pekerjaan dengan mengandalkan keahlian dan bakat saja tanpa adanya kreativitas maka usaha tersebut akan kalah dengan usaha lain di luar sana (Marasabessy \& Santoso, 2014).

Beberapa temuan penelitian terdahulu mengatakan bahwa kreativitas menjadi hal penting bagi organisasi karena dapat membantu menciptakan ide yang belum pernah ada, sehingga dikembangkan menjadi suatu penemuan penciptaan ide baru dalam persaingan di pasar global (Lestari, 2009). Kreativitas memiliki kegunaan yang sangat penting karena merupakan sebuah permulaan dalam menciptakan kreativitas baru (Supriyadi \& Tresna, 2017). Kreativitas baru merupakan inovasi yang dikembangkan dan dikelola menjadi investasi yang berharga bagi keberhasilan suatu perusahaan, sehingga dapat mengubah kreativitas menjadi ide yang cemerlang (Maringan, 2015). Berfikir kreatif juga bermanfaat untuk mendapatkan produk yang berguna berupa inovasi dan jasa yang sulit ditiru oleh orang lain (Wijayanti \& Supartha, 2019). Ada beberapa indikator kreativitas menurut beberapa sumber yang dapat dijadikan sebagai pengukuran kreativitas yaitu pertama memiliki rasa ingin tahu yang besar, mempunyai pendapat sendiri dan dapat mengungkapkan, tidak mudah terpengaruh oleh orang lain, orisinal, dapat bekerja sendiri, senang mencoba hal-hal baru, kemampuan elaborasi, kelancaran dan kefleksibelan (Munandar, 2015). Kedua bersikap terbuka terhadap pengalaman baru, Inovatif, keinginan untuk menemukan dan meneliti (Sund, 2015). Ketiga kemampuan bekerja keras, pantang menyerah dan mampu berkomunikasi dengan baik (Campbell, 2020). Keempat suka berimajinasi dan mencari solusi dari masalah (Lestari, 2009). Dari hasil uraian di atas, tujuan penelitian ini adalah untuk menganalisis kreativitas karyawan dalam menciptakan peluang kesempatan kerja baru di masa pandemic Covid-19.

\section{METODE}

Metode penelitian yang digunakan adalah penelitian kualitatif dengan model deskriptif. Penelitian kualitatif adalah metode penelitian mengumpulkan dan menganalisis data berdasarkan realitas sosial menjadi informasi (Sugiono, 2018). Sesuai dengan tujuan penelitian yang ingin dicapai adalah untuk menganalisis kreativitas karyawan dalam menciptakan peluang kesempatan kerja baru. Sumber data primer dari penelitian ini adalah 10 karyawan yang kena PHK di masa pandemi covid-19. Pengumpulan data dalam penelitian ini menggunakan kuesioner. Kuesioner yang digunakan merupakan jenis kuesioner terbuka dimana kuesioner yang jawabannya di isi oleh responden. Data dianalisis dengan menggunakan teknik analisis deskriptif, dengan menggunakan teknik purposive sampling kemudian teknik penentuan disesuaikan dengan tujuan dari penelitian (Sugiyono, 2018). Narasumber yang ditunjuk adalah karyawan yang kena PHK dalam menciptakan pekerjaan baru sehingga dapat memberikan informasi secara mendalam. 


\section{HASIL DAN PEMBAHASAN}

\section{Hasil}

Berdasarkan hasil kuesioner yang disebarkan kepada 10 responden yaitu para karyawan yang kena PHK selama masa pandemi covid-19 pada tanggal 25 Juni 2021 dan diambil pada 6 juli 2021, maka dapat diperoleh gambaran responden laki-laki delapan orang dan perempuan dua orang, dari segi usia termuda 25 tahun dan yang tertua 37 tahun, yang berumur 25-30 enam orang dan 31-37 tahun empat orang, dari segi pendidikan empat orang lulusan SMA, satu orang lulusan SMK, lima orang lulusan S1 dan satu orang lulusan S3, dari latar belakang perusahaan sebelum di PHK R1 dan R6 berasal dari industry yang sama, yang membedakan R1 industri elektronik dan otomotif sedangkan R6 industri otomotif. R2 dan R3 berasal dari industri yang sama, R2 industri makanan dan R3 industri makanan dan minuman. R4, R5, R7, R9, dan R10 dari industri penerbangan dan R8 dari industri jasa konsultan.

Berdasarkan hasil analisis kuesioner terkait karyawan PHK di masa pandemi covid 19 menciptakan lapangan pekerjaan baru, maka diperoleh hasil sebagai berikut. Pertama, memiliki Rasa ingin tahu yang besar dalam menemukan, meneliti dan mencoba hal-hal baru. Sangat penting memiliki rasa ingin tahu mengenai penciptaan lapangan kerja baru. Mewakili jawaban dari R6 mengatakan bahwa "penting memiliki rasa ingin tahu yang besar karena rasa ingin tahu membuat diri untuk mengetahui dan mencari tahu lebih mengenai penciptaan lapangan kerja baru". Kemudian dua responden mengatakan tidak begitu ingin tahu mengenai penciptaan lapangan kerja baru karena pandemi membuat pekerjaan sulit dilakukan sekarang ini. Berdasarkan hasil kuesioner dapat peneliti simpulkan bahwa indikator rasa ingin tahu membantu dalam penciptaan lapangan kerja baru Hasil responden menunjukkan bahwa rasa ingin tahu merupakan awal untuk mencari tahu lebih dalam bagaimana penciptaan lapangan kerja. Dalam mencoba hal-hal baru mengenai penciptaan lapangan pekerjaan, empat orang mengatakan bahwa mereka akan mencoba berbagai usaha dalam menciptakan lapangan pekerjaan. Mewakili keempat responden, R7 mengatankan "mencoba berbagai usaha dalam menciptakan lapangan kerja sebagai upaya penciptaan lapangan kerja baru". Sedangkan enam responden lainnya mengatakan bahwa mereka senang mencoba hal-hal baru. Mewakili keenam responden, R3 mengatakan "senang mencoba hal-hal baru sebagai upaya memaksimalkan penciptaan lapangan pekerjaan baru, tidak ada salahnya mencoba hal-hal baru untuk mendapatkan pengalaman baru yang harus disikapi dengan sebaik-baiknya. Semakin mencoba hal-hal baru semakin banyak pengalaman baru yang kita dapatkan".

Kedua, mampu mengembangkan gagasan pemecahan masalah, dapat bekerja sendiri dan mampu berkomunikasi dengan baik. Terkait bagaimana yang terkena PHK memikirkan cara mencari lapangan kerja baru. Sangat perlu memikirkan cara mencari ide pekerjaan baru dengan menciptakan pekerjaan yang tidak begitu bergantung dengan kondisi pandemi covid-19, sehingga ditemukan bahwa di situasi pandemi covid 19 ada sejumlah usaha yang tidak bergantung dengan pandemi covid-19 menurut beberapa responden yaitu R1 usaha laundy, R4 bisnis tanaman hias, R7 usaha karting, R8 usaha bengkel dan motor, R9 bisnis toko online dan R10 usaha frozen food. Dalam mengembangkan gagasan sehingga tercipta ide lapangan pekerjaan baru dari 10 responden, enam di antara akan mencari dan memikirkan cara menciptakan pekerjaan baru dengan mencari peluang usaha di sosial media, mewakili keenam responden, R1 mengatakan "akan mencari referensi pekerjaan di masa pandemi dari media cetak maupun online". Sedangkan empat lainnya mencoba hal-hal kratif dalam menciptakan lapangan kerja baru, mewakili keempat responden, R10 mengatakan yaitu "mencoba hal-hal kreatif yang bisa dilakukan dalam menciptakan peluang usaha baru". Dengan mengembangkan ide kreatif yang dimiliki sehingga tercipta lapangan kerja baru. Berkomunikasi dengan baik dalam dunia pekerjaan sangat membantu untuk saling memahami satu sama lain. Dapat menghindari kesalahpahaman dan tentunya akan saling memberikan rasa nyaman dan membangun hubungan baik dengan rekan kerja. Terkait memiliki kemampuan berkomunikasi yang baik membantu dalam menciptakan lapangan kerja baru. Dari 10 responden, R1 mengatakan "Dalam menciptakan lapangan pekerjaan komunikasi salah satu faktor penting dalam keberhasilan pencapaian usaha. Dengan berkomunikasi yang baik pebisnis dapat mengembangkan usaha yang dimiliki dan juga dapat menghindari kesalahpahaman antara rekan kerja. Kemudian jawaban dari R8 mengatakan bahwa "berkomunikasi yang baik bisa meningkatkan percaya diri serta kepercayan orang lain dalam mendukung terciptanya lapangan kerja yang akan dijalankan".

Mengenai penciptaan lapangan kerja tanpa bantuan orang lain. Sembilan responden mengatakan bahwa dengan mengembangkan suatu usaha tentu sangat diperlukan bantuan orang lain. Mewakili kesembilan responden, R3 mengatakan "saya sangat membutuhkan orang lain agar memiliki relasi yang banyak dalam membantu penciptaan lapangan kerja baru karena bagaimanapun kita tidak bisa bekerja tanpa bantuan orang lain melainkan sangat membutuhkan bantuan orang lain". Sedangkan R4 mengatakan "tanpa bantuan orang lain karena menggunakan modal sendiri". Sehingga dari jawaban 
responden tersebut dapat disimpulkan bahwa dalam mengembangkan usaha sangat diperlukan bantuan orang lain. Ketiadaan kendala membantu dalam penciptaan lapangan kerja baru. dari 10 responden mengatakan bahwa dalam penciptaan lapangan kerja baru banyak kendala yang dihadapi. Mewakili kesepuluh responden tersebut, R2 mengatakan bahwa "kendala pasti ada, dalam menciptakan lapangan kerja pasti menemukan banyak kendala jika tidak ada kendala kita akan terlalu nyaman dengan ketiadaan kendala. Namun ketika ada kendala sebaiknya kita berusaha untuk menyelesaikannya dengan baik". Dalam menghadapi kendala sangat diperlukan solusi bagaimana untuk menyelesaikan masalah tersebut. Hasil kuesioner mengenai komponen mencari solusi membantu dalam menciptakan lapangan pekerjaan. Dari 10 responden mengatakan bahwa sangat berperan ketiadaan kendala. Mewakili kesepuluh responden, R2 mengatakan "Sangat berperan komponen mencari solusi dalam mencari dan menciptakan lapangan kerja baru, awal di PHK saya sudah berupaya mencari solusi dalam mencari dan menciptakan lapangan kerja baru di tengah pandemi saat ini salah satunya adalah dengan berinovasi". Kemudian R6 juga mengatakan "setiap kendala akan menjadi pembelajaran untuk penciptaan lapangan kerja baru" Jadi ketiadaan kendala tidak membantu dalam menciptakan lapangan kerja baru karena setiap pekerjaan yang dilakukan kedepannya akan berhadapan dengan berbagai kendala.

Ketiga, bersikap terbuka terhadap pengalaman baru dan fleksibel. Keterbukaan pada pengalaman tidak hanya menerima pengalaman yang diberikan, tetapi juga dapat menggunakannya dalam membuka kesempatan-kesempatan baru. Terkait bersikap terbuka terhadap pengalaman baru penting dalam penciptan lapangan pekerjaan. Dari 10 responden, dua responden yang mengatakan tidak begitu terbuka tanpa penjelasan dan delapan responden yang mengatakan sangat penting terbuka terhadap pengalaman baru. Mewakili kedelapan responden R1 mengatakan "Penting bersikap terbuka dengan semua orang mengenai pengalaman baru yang dimiliki karena dari situlah seseorang dapat menambah relasi dalam dunia pekerjaan sehingga dapat mengembangkan pemikiran dalam merencanakan suatu inovasi". Menjadi pekerja yang fleksibel banyak memberikan manfaat dan membantu mengatasi perubahan dalam menciptakan ide pekerjaan baru. Terkait seberapa berperan kefleksibelan dalam menciptakan lapangan kerja baru. Dari 10 responden, dua responden mengatakan fleksibel mungkin tanpa penjelasan dan delapan responden mengatakan sangat fleksibel. Mewakili kedua responden, R3 mengatakan "sangat penting kefleksibelan agar lebih mudah menyesuaikan diri dengan linkungan kerja baru".

Keempat, kemampuan bekerja keras, pantang menyerah dan mampu berkomunikasi dengan baik. Terkait kemampuan bekerja keras berperan dalam penciptaan lapangan kerja baru. Dari 10 responden mengatakan bahwa penting bekerja keras dalam penciptaan lapangan pekerjaan baru. Mewakili 10 responden, R4 mengatakan "kemampuan bekerja keras sangat berpengaruh karena dapat mendorong dan membuat usaha saya berkembang dengan baik". Sehingga kemampuan bekerja keras sangat dibutuhkan dalam penciptaan lapangan kerja baru agar memaksimalkan penciptaan lapangan pekerjaan. Terkait sikap pantang menyerah dalam mencari lapangan pekerjaan baru dari 10 responden, dua responden mengatakan cukup penting tanpa penjelasan dan delapan responden mengatakan sangat berpengaruh sikap pantang menyerah dalam penciptaan lapangan pekerjaan baru. Mewakili delapan responden, R4 mengatakan "sangat penting pantang menyerah karena seseorang harus memiliki sikap pantang menyerah untuk berusaha dalam menjalankan usaha". Dengan berfikir pantang menyerah pekerjaan yang akan di kembangkan akan berjalan sesuai dengan yang diinginkan.

Kelima, suka berimajinasi dan Inovatif. Terkait sejauh mana kemampuan berimajinasi membantu dalam menciptakan lapangan pekerjaan. Dari 10 responden, dua responden mengatakan tidak begitu menggunakan imajinasi dalam beraktivitas dan delapan responden banyak berimajinasi dalam penciptaan lapangan kerja baru. Mewakili delapan responden, R1 mengatakan "berimajinasi sangat membantu dalam menciptakan lapangan pekerjaan karena terdapat keterkaitan khusus antara imajinasi dan kreatif dalam berwirausaha yaitu dapat menciptakan inovasi dan kreativitas bisnis sehingga berimajinasi dapat membantu menciptakan ide pekerjaan baru". Kemudian kemampuan inovatif dengan mendayagunakan pemikiran dan kemampuan berimajinasi dapat mengembangkan halhal baru yang diperlukan dalam meningkatkan produktivitas dalam bekerja. Sebagaimana terkait indikator sejauh mana inovasi berpengaruh terhadap penciptaan lapangan kerja. 10 responden mengatakan inovasi sangat dibutuhkan dalam penciptaan lapangan kerja. Mewakili 10 responden, R1 mengatakan "inovasi sangat dibutuhkan dalam menciptakan lapangan kerja karena dengan berfikir inovasi seseorang dapat bersaing dengan pesaing usaha lainnya Inovasi sangat berperan penting dalam kemajuan sebuah usaha yang baru di kembangkan". Sehingga dapat disimpulkan bahwa berimajinasi dan berinovatif sangat berperan dalam penciptaan lapangan kerja baru agar lebih meningkatkan daya berfikir seseorang dalam mengembangkan suatu usaha penciptaan lapangan kerja baru.

Berdasarkan hasil yang telah diperoleh dari penelitian bahwa karyawan memiliki rasa ingin tahu yang besar mengenai penciptaan lapangan kerja. Sebelum merencanakan pekerjaan sebaiknya 
mencari tahu terlebih dahulu tujuan menciptakan pekerjaan seperti apa sehingga tepat sasaran dan lebih inovatif. Keinginan menemukan dan meneliti penting dalam penciptaan lapangan kerja agar menciptakan pekerjaan memiliki tujuan yang jelas. Tidak mudah memikirkan ide pekerjaan baru namun banyak cara yang dapat dilakukan seperti, memikirkan peluang pekerjaan yang tidak bergantung pada pandemi covid-19. sehingga ditemukan bahwa di situasi pandemi covid-19 ada sejumlah usaha yang tidak bergantung dengan pandemi covid-19. Rasa ingin tahu adalah tindakan untuk mengetahui mendalam dan meluas dari apa yang ingin diketahui(Citra Ningrum et al., 2019). Ketika mencoba hal-hal baru tentu banyak tantangan dan ketakutan sendiri maka dari itu perluh mempertimbangkan hal baru yang akan dicoba bisa saja menguntungkan atau merugikan. Setiap karyawan harus memikirkan sendiri bagaimana penciptaan lapangan kerja yang baik kedepannya dengan kreativitas yang muncul dari ide atau gagasan baru yang ada dalam diri untuk menciptakan sebuah inovasi dalam mengembangkan ide kreatif harus dengan menumbuhkan gagasan baru dengan berimajinasi (Lestari, 2009; Widiyanti \& Wisayang, 2021). Terkadang orang yang suka berimajinasi hanya untuk membuang waktu saja, namun bagi orang yang suka berimajinasi seringkali dibutuhkan. Orang yang suka berimajinasi tentu ingin mendapatkan pekerjaan yang cocok dengan bakatnya, namun keahlian orang berbeda-beda dalam setiap mencari lapangan kerja.

Penciptaan lapangan pekerjaan tentu banyak menghadapi masalah. Karena dari sanalah dapat diketahui bahwa apakah bisa menyelesaikan masalah tersebut dengan baik atau tidak. Terkadang tanpa disadari sebuah kendala kecil bisa menjadi besar. Karena itu ketika menghadapi suatu kendala pastikan pikiran tidak terbawa arus terhadap kendala tersebut. Ketiadaan kendala tidak membantu dalam menciptakan lapangan kerja baru, karena setiap pekerjaan yang dilakukan kedepannya akan berhadapan dengan berbagai kendala. Seperti saat ini pandemi covid-19 membuat banyak karyawan yang terkena PHK memikirkan bagaimana upaya agar dapat mencari dan menciptakan lapangan kerja baru. Penciptaan lapangan pekerjaan tentu membutuhkan campur tangan orang lain. Sehingga dapat membangun sebuah usaha dalam dunia pekerjaan karena semakin banyak orang yang kita libatkan semakin besar peluang yang kita dapatkan. Hubungan baik dengan rekan kerja dapat berpengaruh pada kinerja karena selama bekerja akan selalu bertemu dan berhubungan dengan rekan kerja. Apabila terjadi salah komunikasi akan berdampak buruk pada kinerja dan produktivitas kerja. Untuk itu kemampuan berkomunikasi dengan baik membantu dalam menciptakan lapangan kerja baru. Sangat penting terbuka terhadap pengalaman baru terutama dalam pengembangan penciptaan lapangan kerja baru. Terbuka mengenai pengalaman yang positif kepada semua orang sehingga lebih menambah relasi agar diterima dengan baik di lingkungan. Fleksibel menekankan kemauan dan kemampuan untuk beradaptasi dengan perubahan. Menjadi pekerja yang fleksibel yaitu mampu menyesuaikan diri dengan tantangan yang diterimanya sesuai dengan kebutuhan dalam pekerjaan (Aprilliyani, 2006; Nurrohman et al., 2017). Kefleksibelan dalam pekerjaan baru dapat membantu dalam menyelesaikan perubahan-perubahan baru yang terjadi dalam dunia kerja.

Temuan ini diperkuat dengan penelitian sebelumnya yang menyatakan para pemuda memiliki kemampuan untuk menciptakan lapangan kerja berupa usaha pengecatan kendaraan bermotor. Keberhasilan kegiatan ini diharapkan dapat turut mengurangi tingkat pengangguran yang terjadi di masa pandemi Covid-19 (Maliwemu et al., 2021). Kreativitas menjadi pendukung para pekerja untuk menciptakan ide-ide baru yang kreatif kemudian mengembangkannya, sehingga kreativitas mereka menjadi kekuatan dalam menciptakan pekerjaan (Widiyanti \& Wisayang, 2021). Namun ditemukan di lapangan bahwa pada situasi pandemi sejumlah usaha yang tidak bergantung dengan pandemi covid 19 yaitu usaha jasa laundry, bengkel motor dan mobil, katring, bisnis frozen food, bisnis toko online, dan bisnis tanaman hias. Ketika terkena PHK tentu tidak untuk berdiam diri tetapi berfikir menciptakan lapangan kerja baru dengan memperhatikan pekerjaan yang tidak begitu bergantung pada kondisi pandemi. Seperti mencoba pekerjaan baru melalui kreativitas yang sudah dimiliki sebagai peluang usaha baru.

\section{SIMPULAN}

Berdasarkan analisis data dan hasil pembahasan dapat diperoleh kesimpulan bahwa kreativitas karyawan dalam penciptaan lapangan kerja baru sama dengan teori mencakup 16 hal yaitu; rasa ingin tahu yang besar, memiliki pendapat sendiri, memiliki gagasan pemecah masalah, dapat bekerja sendiri, senang mencoba hal-hal baru, memiliki kemampuan elaborasi, bersikap terbuka terhadap pengalaman baru, inovatif, keinginan menemukan dan meneliti, kelancaran, fleksibel, bekerja keras, pantang menyerah, berkomunikasi dengan baik, suka berimajinasi dan dapat mencari solusi dari masalah. Keterbatasan penelitian ini adalah dalam kondisi pandemi covid-19 menyebabkan penyebaran kuesioner dilakukan secara daring. Peneliti selanjutnya, pertama memperbanyak responden sehingga lebih berkreasi mengenai 
industri dari mana mereka di PHK. Saran kedua yaitu untuk topik penelitian selanjutnya "Pengaruh kreativitas karyawan yang kena PHK terhadap lama waktu penciptaan usaha baru yang didirikan" mungkin metoda kuantitatif bisa menjadi alternatif pilihan.

\section{DAFTAR PUSTAKA}

Adriani, D., \& Wildayana, E. (2015). Integrasi Pertumbuhan Ekonomi Dan Penciptaan Kesempatan Kerja $\begin{array}{lllll}\text { Sektor Pertanian Di Indonesia. Sosiohumaniora, } & \text { 17(3), }\end{array}$ https://doi.org/10.24198/sosiohumaniora.v17i3.8381.

Annisa, N. (2020). Memasuki Normal Baru Usai Pandemi, Penciptaan Lapangan Kerja jadi Hal Penting yang Harus Didahukan. Www Cirebon.Com.

Aprilliyani, R. (2006). Pengaruh Kreativitas Karyawan Terhadap Pengembangan Inovasi Baru Bagi Perusahaan. Fokus Ekonomi, 1(1), 31-37.

Ardipal, \& Laila, S. (2020). Implementasi Tahap Kreativitas David Campbell Pada Grup Musik RHYTHM Chambers Indonesia. Seni Rupa, 09(April).

Arif, S. (2020). Peluang Industri Pengolahan Seusai Wabah Covid-19. Indonesiadevelopmentforum.Com.

Awali, H. (2020). Urgensi Pemanfaatan E-Marketing Pada Keberlangsungan UMKM di Kota Pekalongan di Tengah Dampak Covid-19. BALANCA: Jurnal Ekonomi Dan Bisnis Islam, 2(1), 1-14. https://doi.org/10.35905/balanca.v2i1.1342.

Cheng, V. C., Wong, S., Chuang, V. W., So, S. Y., Chen, J. H., Sridhar, S., To, K. K., Chan, J. F., Hung, I. F., Ho, P., \& Yuen, K. (2020). The Role of Community-Wide Wearing of Face Mask For Control of Coronavirus Disease 2019 ( COVID-19 ) Epidemic Due to SARS-CoV- 2. Journal of Infection, 81, 107-114. https://doi.org/10.1016/j.jinf.2020.04.024.

Citra Ningrum, C. H., Fajriyah, K., \& Budiman, M. A. (2019). Pembentukan Karakter Rasa Ingin Tahu Melalui Kegiatan Literasi. Indonesian Values and Character Education Journal, 2(2), 69. https://doi.org/10.23887/ivcej.v2i2.19436.

Dewantoro, A. (2019). Pengaruh Optimisme terhadap Kemampuan Identifikasi Peluang Mahasiswa Strata Satu Pada Perguruan Tinggi Di Surabaya. Agora, 7, 6.

Djatmiko, A., \& Pudyastiwi, E. (2020). Obstacles and Challenges of Indonesia'S Micro, Small and Medium Enterprises (Umkm) in Facing the Covid-19 Pandemic. Jurnal Pendidikan Kewarganegaraan Undiksha, 8(1), 35-46.

Febriyanti, G. A. (2020). Dampak pandemi Covid-19 terhadap harga saham dan aktivitas volume perdagangan (Studi kasus saham LQ-45 di Bursa Efek Indonesia). Indonesia Accounting Journal, 2(2), 204 - 214. https://doi.org/10.32400/iaj.30579.

Hamdani, T., \& Detik.com. (2020). Ini Dia Pekerjaan Baru yang Muncul di Tengah Merebaknya Corona. Www.Detik.Com.

Khusnani, A., Khusamudin, M. S. S., Saud, M. J., Maulida, N. I., Hamdani, M. D. Y., \& Andriyan, R. (2019). Analisis Proyeksi Kerja Mahasiswa Pendidikan Geografi Kelas B Angkatan 2018. Majalah Pembelajaran Geografi, 2(1), 48-64.

Lestari, F. (2009). Pengaruh jiwa kewirausahaan dan kreativitas terhadap keberhasilan usaha pada sentra industri rajutan binong jati bandung. Artikel Ilmiah, 14-15.

Makmur, A. (2015). Efektifitas Penggunaan Metode Base Method Dalam Meningkatkan Kreativitas Dan Motivasi Belajar Matematika Siswa Smp N 10 Padangsidimpuan. EduTech, 1(1).

Maliwemu, E. U. K., Adoe, D. G. H., Riwu, D. B. N., Tarigan, B. V., Gusnawati, G., Pah, J. C. A., \& Dwinanto, M. M. (2021). Pengembangan Keterampilan Kewirausahaan di Masa Pandemi COVID-19 melalui Pelatihan Pengecatan Kendaraan Bermotor. JMM (Jurnal Masyarakat Mandiri), 5(2), 686-695. https://doi.org/10.31764/jmm.v5i2.4126.

Marasabessy, Z. A., \& Santoso, B. (2014). Pengaruh dukungan rekan kerja pada kreativitas karyawan dengan autonomi kerja dan efikasi-diri kreatif sebagai pemoderasi. Jurnal Siasat Bisnis, 18(1), 32-44. https://doi.org/10.20885/jsb.vol18.iss1.art4.

Maringan, N. (2015). Tinjauan Yuridis Pelaksanaan Pemutusan Hubungan Kerja (Phk) Secara Sepihak Oleh Perusahaan Menurut Undang-Undang No. 13 Tahun 2003 Tentang Ketenagakerjaan. Jurnal Ilmu Hukum Legal Opinion, 3(13), 1-10.

Muslim, M. (2020). PHK Pada Masa Pandemi Covid-19. ESENSI: Jurnal Manajemen Bisnis, 23(3), 357-370. https://ibn.e-journal.id/index.php/ESENSI/article/view/218.

Nasution, D. A. D., Erlina, \& Muda, I. (2020). Dampak Pandemi COVID-19 terhadap Perekonomian Indonesia. Jurnal Benefita, 5(2), 212 - 224. https://doi.org/10.22216/jbe.v5i2.5313.

Ningsih, M. R., \& Mahfudz, M. S. (2020). Dampak Pandemi Covid-19 Terhadap Manajemen Industri Perbankan Syariah: Analisis Komparatif. Point, 2(1), 1-10. 
https: //doi.org/10.46918/point.v2i1.576.

Nurrohman, A. T., Sunaryo, H., \& Basalamah, M. R. (2017). Analisis Pengembangan Sumber Daya Manusia, Kerjasama Tim dan Kreativitas Terhadap Kinerja Karyawan PT. Mavens Mitra Perkasa Malang. Journal of Chemical Information and Modeling, 110(9), 1689-1699.

Ovaritus Jagom, Y. (2015). Kreativitas Siswa SMP dalam Menyelesaikan Masalah Geometri Berdasarkan Gaya Belajar Visual-Spatial dan Auditory-Sequential. Math Didactic: Jurnal Pendidikan Matematika, 1(3), 176-190. https://doi.org/10.33654/math.v1i3.18.

Pakpahan, A. K. (2020). COVID-19 dan Implikasi Bagi Usaha Mikro, Kecil, dan Menengah. Jurnal Ilmiah Hubungan Internasional, 20(April), 59-64. https://doi.org/10.26593/jihi.v0i0.3870.59-64.

Putri, A. V, \& Irwansyah, I. (2020). Communication Patterns And Media Technology Role In Organization And Society During Pandemic. Journal of Society And Media, 4(2), 228. https: //doi.org/10.26740/Jsm.V4n2.P228-261.

Sugiono. (2018). Metode Penelitian Pendididkan Pendekatan Kuantitatif, Kualitatif, dan R\&D. Alfabeta.

Supriyadi, \& Tresna, M. S. W. (2017). Analisis Kreativitas dan Inovasi Karyawan Bank BRI KCP Unit Pameungpeuk. Journal of Chemical Information and Modeling, 110(9), 1689-1699.

Wibowo, R. F., \& Herawati, R. (2021). Perlindungan Bagi Pekerja Atas Tindakan Pemutusan Hubungan Kerja (PHK) Secara Sepihak. Jurnal Pembangunan Hukum Indonesia, 3(1), 109-120. https://doi.org/10.14710/jphi.v3i1.109-120.

Widiyanti, \& Wisayang, V. R. W. (2021). Inovasi Dan Kreativitas Kang Bagong Catering Semarang Di Tengah Pandemi. Praxis, 3(2), 82. https://doi.org/10.24167/praxis.v3i2.3034.

Wijayanti, I. A. D., \& Supartha, I. W. G. (2019). Pengaruh Kepemimpinan Transformasional Terhadap Kreativitas Karyawan Dimediasi Efikasi Diri Kreatif Pada Pt. Aura Bali Craft. E-Jurnal Manajemen Universitas Udayana, 8(3), 1230. https://doi.org/10.24843/ejmunud.2019.v08.i03.p03. 